\title{
PERAN KELUARGA DAN KUALITAS HIDUP PASIEN KANKER SERVIKS
}

\author{
(The Role of Family and Quality of Life in Patients with Cervical Cancer)
}

\author{
Tiyas Kusumaningrum*, Retnayu Pradanie*, Esti Yunitasari*, Sih Kinanti** \\ *Divisi Keperawatan Maternitas, Fakultas Keperawatan Universitas Airlangga \\ **Ruang Merak RSUD Dr. Soetomo Surabaya \\ Email: tiyas-k@fkp.unair.ac.id
}

\begin{abstract}
ABSTRAK
Pendahuluan. Diagnosis kanker serviks telah menjadi beban besar baik bagi pasien dan keluarga. Untuk pasien, kanker serviks menghilangkan beberapa peran mereka sebagai istri dan ibu. Kebanyakan pasien kanker dengan stadium lanjut memiliki skor kualitas hidup rendah yang menunjukkan mereka memiliki masalah. Keluarga harus mengurus orang-orang tercinta mereka berurusan dengan diagnosis, pengobatan, dan efek samping dari kanker serviks. Keluarga sebagai pengasuh mungkin tidak siap untuk melakukan peran itu. Tujuan dari penelitian ini adalah untuk mengidentifikasi korelasi tugas kesehatan keluarga pada kualitas hidup pada pasien dengan kanker serviks. Metode. Penelitian ini menggunakan desain cross-sectional. Populasi dalam penelitian ini adalah semua pasien dengan kanker serviks dan keluarga mereka di bangsal ginekologi RS Dr Soetomo Surabaya. Data diambil dengan wawancara terstruktur menggunakan Fact Cx untuk kualitas hidup dan kuesioner tugas kesehatan keluarga. Analisis regresi linier diaplikasikan dengan tingkat signifikansi $\leq 0.05$. Hasil. Sebagian besar keluarga memiliki tugas kesehatan keluarga tingkat sedang, sedangkan mayoritas pasien juga memiliki kualitas hidup tingkat sedang. Tidak ada korelasi yang signifikan antara tugas kesehatan keluarga pada kualitas hidup pada pasien dengan kanker serviks. Diskusi. Kualitas hidup pada pasien dengan kanker serviks tidak terpengaruh secara langsung oleh tugas kesehatan keluarga mereka. Meskipun demikian pasien merasa bersyukur bahwa keluarga mereka sangat mendukung selama pengobatan kanker mereka.
\end{abstract}

Kata kunci: tugas keluarga kesehatan, kenyataannya cx, dukungan keluarga, kualitas hidup, kanker serviks

\begin{abstract}
Introduction. Cervical cancer diagnosis has been a major burden both for patients and their family. For patients, cervical cancer obliterated some of their role as a wife and a mother. Most patients with advance cancer have low score of quality of life indicating they have problems. Family must take care of their beloved ones dealing with the diagnosis, treatment, and side effects of cervical cancer. Family as a caregiver might be ill prepared to undertake that role. The objective of this research was to identify the correlation of family health task on quality of life in patients with cervical cancer. Methods. This research employed cross-sectional design. Population in this research was all patients with cervical cancer in gynecology ward Dr Soetomo Hospital in Surabaya. Participant for this research were patients with cervical cancer and their family. Data were taken by structured interview using Fact Cx for Quality of life and family health task question form. Linear regression analysis was applied with level of significance $\leq 0.05$. Results. Most family had moderate level of family health task while most patients also have moderate level of quality of life. Unfortunately there are no significance correlations of family health task on quality of life in patients with cervical cancer. Discussion. Quality of life in patient with cervical cancer was not affected directly by their family health task. Nonetheless patient gratefully thanks family for their support during their cancer treatments.
\end{abstract}

Keywords: family health task, fact cx, family support, quality of life, cervical cancer

\section{PENDAHULUAN}

Kanker serviks merupakan jenis kanker ginekologis paling sering terjadi pada wanita (Cunningham 2005). Penderita kanker serviks terutama pada stadium lanjut mempunyai berbagai keluhan yaitu nyeri panggul, kelelahan, perdarahan spontan, penurunan nafsu makan, sesak napas, konstipasi, dan kesulitan berkemih (Dunleavey 2009). Dukungan keluarga sangat dibutuhkan pasien kanker serviks dalam menghadapi kehidupan paska diagnosis kanker dan penanganannya. Terdapat lima tugas kesehatan keluarga sebagai bagian dari fungsi keluarga dalam perawatan kesehatan antara lain; keluarga mampu mengenali permasalahan yang ada, mampu mengambil keputusan tindakan kesehatan yang tepat, mampu merawat anggota keluarga yang sakit, mampu memelihara kesehatan lingkungan, dan mampu menggunakan fasilitas kesehatan yang tersedia (Basavanthappa 2008).

Angka kejadian kanker serviks sangat tinggi terutama di negara berkembang. Perkiraan angka kejadian kanker serviks di USA pada tahun 2010 adalah 12.200 kasus baru, dan 4.210 kematian (NCI 2010). Kejadian kanker serviks per tahun di Indonesia sejumlah 13.762 kasus dan 7.493 kematian. Kanker serviks merupakan kanker ketiga terbanyak 
yang terjadi pada wanita di Indonesia, serta kanker kedua yang paling sering terjadi pada wanita usia 15 tahun sampai dengan 44 tahun (WHO 2010). Menurut Data Dinas Kesehatan Jawa Timur pada tahun 2011 terdapat 901 perempuan dengan diagnosa neoplasma ganas serviks, dengan jumlah pasien rawat inap sebanyak 790 kasus (Dinkes \& PPMK 2012).

Berbagai upaya peningkatan kondisi pasien paska kemoterapi telah banyak dilakukan. Pemberian penyuluhan selama perawatan pada pasien kanker serviks dan keluarga sudah dilaksanakan di ruang rawat pasien kanker serviks. Pada beberapa pasien, penyuluhan diterima dengan baik namun pada kebanyakan pasien tetap mengalami penurunan kondisi paska kemoterapi. Usia pasien kanker serviks umumnya diatas 35 tahun dan berpendidikan rendah sehingga sulit untuk menerima informasi yang cukup banyak dalam satu waktu penyuluhan. Keluarga diharapkan berperan aktif untuk dapat membantu pasien kanker serviks memahami informasi yang diberikan petugas kesehatan serta terlibat dalam perawatan pasien baik di rumah maupun di rumah sakit. Keterlibatan keluarga dalam membantu pasien menghadapi proses pengobatan kanker serviks dapat membantu pasien kanker serviks mencapai kualitas hidup yang optimal.

\section{BAHAN DAN METODE}

Design penelitian yang digunakan adalah cross-sectional. Pengamatan atau pengukuran setiap variabel dalam penelitian ini hanya akan dilangsungkan satu kali saja dan tidak ada pengukuran atau observasi ulang maupun lanjutan. Populasi pada penelitian ini adalah seluruh keluarga penunggu pasien kanker serviks di ruang Merak RSUD Dr. Soetomo pada bulan Oktober sampai dengan November 2013 berjumlah 48 orang. Responden yang berpartisipasi dalam penelitian ini berjumlah 28 orang yang dipilih berdasarkan kriteria inklusi dan eksklusi. Mayoritas responden keluarga adalah perempuan sedangkan untuk responden pasien seluruhnya berjenis kelamin perempuan. Teknik pengambilan sampling yang digunakan adalah consecutive sampling.

Variabel dalam penelitian ini adalah lima tugas kesehatan keluarga (pengetahuan, kemampuan pengambilan keputusan kesehatan, kemampuan memelihara lingkungan sehat, kemampuan menggunakan fasilitas kesehatan, dan kemampuan merawat keluarga) dan kualitas hidup pasien kanker serviks. Instrumen yang digunakan dalam penelitian ini adalah kuesioner lima tugas kesehatan keluarga dan kuesioner Fact $C x$ untuk mengukur kualitas hidup pasien kanker serviks. Wawancara terstruktur berdasarkan kuesioner tersebut diterapkan pada pasien maupun keluarga. Hal ini dilakukan karena permintaan responden yang merasa bahwa mereka akan lebih memahami jika kuesioner tersebut ditanyakan oleh peneliti. Data yang didapatkan diolah menggunakan uji statistik linear berganda.

\section{HASIL}

Sebagian besar responden keluarga dalam penelitian ini telah mendapatkan informasi tentang kanker serviks. Informasi yang dimiliki keluarga biasanya didapatkan dari petugas kesehatan di RSUD Dr Soetomo. Informasi yang banyak dipahami oleh responden adalah tentang definisi kanker serviks dan kegawatan penyakit tersebut sedangkan informasi tentang penanganan dan efek samping pengobatan belum dipahami dengan baik. Responden pasien mayoritas adalah pasien kanker serviks yang berada pada stadium IIB.

Kemampuan keluarga menjalankan lima tugas kesehatan keluarga mayoritas pada tingkat baik. Pada komponen penggunaan layanan kesehatan dan keterampilan keluarga dalam merawat pasien kanker serviks, kemampuan keluarga merata pada tingkat baik, cukup, dan kurang.

Sebagian besar pasien kanker serviks mempunyai kualitas hidup pada tingkat baik dan cukup namun tidak ada tingkat kualitas hidup ppasien yang dominan dalam penelitian ini. Komponen kualitas hidup pasien kanker serviks yang mempunyai rerata skor terendah adalah komponen keadaan fisik. Pada komponen keadaan fisik pasien banyak mengeluhkan tentang pengeluaran cairan keputihan atau perdarahan pervaginam serta masalah yang ditimbulkan oleh cairan tersebut seperti gatal, dan bau tidak sedap. Pasien kanker serviks menyatakan bahwa mereka mendapat dukungan dari keluarga dalam menghadapi penyakit dan pengobatannya. Pada komponen perhatian khusus tidak ada pasien yang menyatakan ingin hamil lagi. Rerata usia pasien lebih dari 35 tahun dan atau telah memiliki jumlah anak yang cukup. 
Hasil regresi variabel lima tugas kesehatan keluarga terhadap nilai skor Fact $C x$ (quality of life) adalah sebesar 0,301. Hal ini menunjukkan terdapat hubungan yang rendah antara variabel lima tugas kesehatan keluarga dengan quality of life pasien kanker serviks di Ruang Merak RSUD Dr. Soetomo. Hasil analisis determinasi menunjukkan hasil $\mathrm{R}^{2}$ adalah 0,091 yang berarti bahwa sumbangan pengaruh lima tugas kesehatan keluarga terhadap variabel quality of life adalah sebesar $9,1 \%$. Hasil regresi menunjukkan bahwa $\mathrm{F}$ hitung adalah 0,340 sedangkan jika dibandingkan dengan $\mathrm{F}$ tabel adalah 2,964. Nilai $F$ hitung lebih kecil dari nilai $F$ tabel mengindikasikan bahwa tidak ada pengaruh lima tugas kesehatan keluarga dengan nilai quality of life pasien kanker serviks.

Pengujian koefisien regresi variabel lima tugas kesehatan keluarga dilakukan untuk mengetahui adanya pengaruh secara parsial dari variabel tersebut dengan nilai kualitas hidup pasien kanker serviks (Fact $C x$ ). Tabel distribusi t dicari pada $\alpha=0.25$ (uji dua sisi) dengan $\mathrm{df}=\mathrm{n}-\mathrm{k}-1$ yaitu 17 . Dengan pengujian dua sisi didapatkan $\mathrm{t}$ tabel yaitu 2,1098. Hasil $\mathrm{t}$ hitung untuk seluruh variabel lima tugas kesehatan keluarga menunjukkan nilai dibawah $t$ tabel. Perbandingan $t$ hitung dan $t$ tabel tersebut menunjukkan bahwa tiap variabel lima tugas kesehatan keluarga secara parsial tidak berpengaruh secara signifikan terhadap nilai Fact $C$ x. Konstanta menunjukkan nilai 80,587 berarti bahwa jika nilai semua komponen lima tugas kesehatan keluarga adalah 0 maka skor Fact $C x$ adalah 80,587.

\section{PEMBAHASAN}

Penelitian ini menunjukkan hasil bahwa sebagian besar responden yang merupakan keluarga penunggu pasien kanker serviks yang dirawat di ruang Merak RSUD Dr. Soetomo memiliki skor lima tugas kesehatan keluarga dalam kategori cukup. Kemampuan keluarga yang baik dalam melaksanakan lima tugas kesehatan keluarga dapat menjadikan keluarga sebagai pemberi perawatan yang efektif bagi anggota keluarga yang sakit (Friedman et al. 2003). Keluarga yang dapat menjalankan fungsi perawatan kesehatan untuk keluarga yang sakit dapat membantu anggota keluarga yang sakit mencapai kondisi yang lebih baik secara fisik maupun psikologis.
Jenis informasi yang diterima oleh responden sangat beragam namun sebagian besar tentang definisi penyakit kanker serviks dan kondisi lanjut yang mungkin dialami oleh pasien jika tidak segera melakukan perawatan. Setiap keluarga maupun pasien kanker mempunyai kebutuhan yang beragam akan informasi yang diinginkan tentang penyakit yang sedang dihadapi. Informasi tentang diagnosis dan penatalaksanaan medis merupakan hal yang diharapkan pada masa awal penegakan diagnosis pasien kanker, sedangkan informasi tentang topic non medis seperti cara koping dan membina hubungan yang baik dengan pasien kurang diminati (Adams et al. 2009). Sebuah review tentang pencarian informasi oleh keluarga pasien kanker yang dilakukan oleh McCarthy (2011) memperlihatkan hasil bahwa keluarga mencari informasi tentang kesehatan pasien melalui empat cara. Cara tersebut antara lain mendampingi pasien saat kontrol, membuat janji bertemu dengan petugas kesehatan bersama dengan pasien, langsung menemui petugas kesehatan, dan membawa hadiah untuk petugas kesehatan. Dari keseluruhan responden hanya tujuh orang responden yang menyatakan belum mendapatkan informasi tentang kanker serviks (McCarthy 2011). Sebagian responden yang menyatakan belum mendapatkan informasi menjelaskan bahwa mereka percaya dengan segala tindakan yang akan dilakukan oleh petugas kesehatan dan mereka merasa lebih cemas jika mengetahui lebih banyak tentang penyakit pasien. Sebuah penelitian tentang kebutuhan keluarga akan informasi yang dilakukan oleh Andreassen menunjukkan bahwa diantara keluarga pasien kanker, sebagian kecil memang tidak menginginkan banyak informasi. Tingkat pengetahuan keluarga tentang penyakit kanker serviks dapat dipengaruhi oleh cara keluarga memperoleh informasi serta latar belakang pendidikan keluarga serta aspek psikologis yang perlu untuk dilakukan penelitian lebih lanjut (Andreassen et al. 2005).

Sebagian pasien kanker serviks di Indonesia datang pada stadium yang lanjut dan membutuhkan penatalaksanaan medis yang cepat sehingga keluarga tidak mempunyai banyak pilihan dan waktu dalam memutuskan hal yang harus dilakukan untuk anggota keluarga yang sakit. Sebagian responden dalam penelitian ini bergender perempuan namun diantara mereka menyeatakan tidak menemui banyak kesulitan dalam memutuskan rencana perawatan kesehatan untuk anggota keluarga 
mereka. Hampir seluruh responden perempuan adalah wanita bekerja yang mendapatkan penghasilan perbulan dari pekerjaan mereka sebagai cara mereka membantu perekonomian keluarga. Sebagian besar responden menyatakan bahwa setiap keputusan yang mereka ambil untuk anggota keluarga yang sakit kanker serviks adalah hasil dari musyawarah yang dilakukan dengan anggota keluarga yang lain meskipun pada akhirnya keputusan tetap berada pada responden. Perempuan yang mempunyai pekerjaan tetap dan penghasilan yang setara dengan laki-laki dalam keluarga cenderung mempunyai kesetaraan dalam menyampaikan pendapat dan ikut andil dalam keputusan dalam keluarga. Peran anggota keluarga lain dalam membantu mempertimbangkan keputusan yang tepat sangat diperlukan sehingga keluarga yang bertanggung jawab atas pasien kanker serviks yakin akan keputusan yang diambil dan tidak merasa menyesal pada keputusan yang telah mereka buat. Petugas kesehatan baik dokter maupun perawat juga memegang peranan untuk memberi gambaran pada responden tentang kondisi kesehatan pasien kanker serviks sehingga dengan informasi yang diberika oleh petugas kesehatan, keluarga dapat mengambil keputusan yang tepat yang telah disertai dengan pertimbangan sebelumnya tentang baik buruknya penatalaksanaan yang akan diterapkan pada pasien kanker serviks.

Sebagian besar responden keluarga sudah mampu untuk membuang sampah pada tempatnya, menguras tempat penampungan air seperti bak mandi dan wadah air minum, keluarga juga telah menyediakan tempat sampah di dalam rumah, dan membersihkan tempat buang air sesuai kebutuhan serta menyediakan dan menggunakan sabun antiseptik di kamar mandi mereka. Meskipun sebagian besar responden sudah mampu menjaga kebersihan lingkungan, terdapat tiga responden yang tidak mempunyai kakus pribadi. Satu responden menggunakan kamar mandi umum dan dua responden tidak menggunakan kakus namun menggunakan lobang pembuangan untuk buang air. Sebagian besar responden meskipun menyediakan tempat sampah di dalam rumah namun tempat sampah yang ada tidak mempunyai penutup tempat sampah yang memungkinkan binatang untuk masuk. Menggunakan air bersih, mencuci tangan menggunakan sabun, menggunakan jamban sehat, dan membersihkan tempat penampungan air merupakan empat dari sepuluh indikator Perilaku Hidup Bersih dan Sehat yang disingkat menjadi PHBS (Setyani 2013). Lingkungan memberikan pengaruh yang besar pada resiko dan kejadian kanker (Kerrigan \& Kelly 2010). Pasien kanker serviks yang mendapatkan kemoterapi ataupun radioterapi akan mengalami kondisi kesehatan yang menurun karena efek samping kanker serviks yang menurunkan imunitas tubuh pasien kanker serviks (Dunleavey 2009). Keluarga diharapkan dapat menjaga keberrsihan lingkungan tempat pasien kanker serviks dirawat sehingga pasien kanker yang lebih rentan mendapatkan penyakit lain karena penurunan kondisinya dapat terhindar dari kesakitan akibat lingkungan yang tidak bersih.

Skor penggunaan layanan kesehatan berimbang antara kategori baik, cukup, dan kurang. Mayoritas responden adalah perempuan dan perempuan merupakan tokoh penting dalam program kesehatan keluarga di Indonesia. Hal ini terbukti pada jumlah kader posyandu yang mayoritas adalah perempuan.

Sebagian besar responden menyatakan telah menggunakan fasilitas pelayanan kesehatan milik pemerintah yang disediakan di sekitar wilayah tempat tinggal mereka, namun hanya beberapa dari mereka berperan aktif dalam program yang dicanangkan oleh pelayanan kesehatan tersebut. Para responden tersebut berperan aktif karena mereka adalah kader atau didalam keluarga yang satu rumah menjadi kader Posyandu. Kader kesehatan memang dipilih dari anggota masyarakat untuk meningkatkan kepercayaan diri masyarakat dalam meningkatkan derajat kesehatan lingkungan tempat tinggalnya (Effendy 1998). Sebagian besar responden yang kurang aktif hanya memanfaatkan Puskesmas atau rumah sakit pemerintah untuk berobat saat sakit ataupun meminta surat rujukan untuk dilanjutkan ke rumah sakit pemerintah dengan tipe yang lebih tinggi. Kurangnya pemanfaatan tempat pelayanan kesehatan primer dan daerah oleh responden disebutkan bahwa responden sering menunda pengobatan atau pergi ke klinik umum karena khawatir mendapatkan pelayanan yang lama di Puskesmas atau RS daerah. Sebagian kecil responden juga masih lebih memilih obat paten dibandingkan dengan obat generic yang disarankan pemerintah dan tersedia secara murah atau gratis di tempat pelayanan kesehatan milik pemerintah. Kurangnya minat masyarakat menggunakan layanan kesehatan milik pemerintah pernah 
diteliti pada tahun 2001 dengan hasil bahwa sebagian besar masyarakat yang menggunakan layanan kesehatan milik pemerintah merasa kurang puas dengan pelayanan yang diberikan dibandingkan dengan pelayanan di klinik atau RS swasta (Setyowati \& Lubis 2003).

Terdapat kecenderungan bahwa responden dengan keluarga pasien kanker serviks yang mempunyai keterbatasan fisik dan skor kualitas hidup rendah mempunyai keterampilan merawat lebih baik dibandingkan dengan responden yang keluarga menderita kanker serviks mempunyai kondisi fisik yang lebih baik. Pasien kanker serviks stadium lanjut mendapatkan penanganan seperti kemoterapi dan radioterapi yang memberikan efek samping kelemahan pada pasien (Dunleavey 2009). Pasien kanker yang berada pada stadium lanjut membutuhkan perhatian dan perawatan lebih dari keluarga (Given et al. 2001). Keluarga dengan pasien kanker serviks yang mengalami kelemahan akan mendapatkan pengalaman dalam membantu segala aktivitas pasien selama di rumah. Keluarga yang terbiasa membantu kegiatan pasien maka dalam penilaian keterampilan memberi performa yang lebih baik jika dibandingkan dengan keluarga yang belum memiliki pengalaman membantu aktivitas pasien.

Rerata terendah dari keseluruhan komponen Fact $\mathrm{Cx}$ adalah skor keadaan fisik pasien kanker serviks. terdapat lebih dari dealapan pasien kanker serviks yang mempunyai skor kurang dari 10. Sebagian besar pasien menjawab bahwa mereka sering merasa tidak bertenaga, kadang hilang nafsu makan, selalu merasakan nyeri dengan skala nyeri yang beragam, dan terganggu dengan eefek samping pengobatan seperti mual, muntah, kelemahan dan perubahan penampilan. Pengobatan kanker selalu memberikan efek samping pada pasien yang beragam tergantung dari tipe kanker serta jenis obat atau terapi yang diberikan (Catane et al. 2006).

Hasil analisis statistic menunjukkan bahwa Lima Tugas Kesehatan Keluarga tidak berhubungan dengan kualitas hidup pasien kanker serviks baik secara bersama-sama maupun secara parsial. Sebagian besar responden dengan pasien kanker serviks yang memiliki keterbatasan dalam melaksanakan aktivitas fisik dan berada pada stadium lebih lanjut mempunyai skor tugas kesehatan yang lebih baik dibandingkan dengan responden yang memiliki anggota keluarga pasien kanker serviks yang berada pada stadium awal atau seri pengobatan awal kanker serviks. Keluarga yang memiliki anggota keluarga mengalami kanker akan berusaha merawat pasien sesuai dengan kebutuhan pasien, namun kurangnya pengalaman dapat menyebabkan keluarga tidak siap dalam menghadapi perubahan peran tersebut (Given et al. 2001). Keluarga dengan pasien kanker serviks yang belum mengalami keterbatasan fisik belum pernah membantu aktivitas pasien secara langsung, perawatan yang mereka berikan terbatas pada mengantar pasien ketika control ataupun berobat, memberi dukungan moral, serta mengingatkan jadwal minum obat pasien. Keluarga yang telah merawat pasien kanker serviks yang mempunyai kondisi buruk akan belajar dari pengalaman mereka dan menerapkan kembali yang mereka pelajari pada situasi yang sama. Pengalaman keluarga tersebut tentu tidak semua sesuai dengan peran yang diharapkan. Keluarga perlu disiapkan dan diinformasikan tentang peran mereka untuk merawat pasien kanker serviks dan hal tersebut disediakan oleh tempat pelayanan kesehatan (Given et al. 2001). Edukasi dan keterlibatan pada keluarga penting untuk diberikan oleh setiap petugas kesehatan sehingga keluarga mampu merawat pasien sesuai kebutuhan (Friedman et al. 2003).

\section{SIMPULAN DAN SARAN}

\section{Simpulan}

Kemampuan keluarga menjalankan lima tugas kesehatan keluarga tidak secara langsung mempengaruhi kualitas hidup pasien kanker serviks. Komponen seperti keadaan fisik, sosial, emosi, peran serta perhatian lain terkait sistem reproduksi lebih berperan untuk menentukan level dari kualitas hidup pasien kanker serviks. Kemampuan keluarga melaksanakan lima tugas kesehatan keluarga meskipun tidak berpengaruh secara langsung dalam membentuk skor kualitas hidup pasien kanker serviks dapat membantu pasien kanker serviks mendapatkan kualitas hidup yang lebih baik.

\section{Saran}

Penelitian ini merekomendasikan kepada perawat dan institusi pelayanan kesehatan khususnya pemerintah baik pusat 
maupun daerah untuk meningkatkan keterlibatan keluarga dalam perawatan kesehatan bagi pasien kanker serviks dengan memberikan informasi dan pelatihan keterampilan yang tepat.

Penelitian selanjutnya sebaiknya menggunakan instrument yang lebih tepat dan lebih sesuai untuk responden dengan kultur dan bahasa Indonesia untuk mempermudah dan meningkatkan validitas pengukuran variabel kemampuan keluarga melakukan lima tugas kesehatan keluarga dan juga pengukuran kualitas hidup pasien kanker serviks.

\section{KEPUSTAKAAN}

Adams, E., Boulton, M., \& Watson, E. (2009). The information needs of partners and family members of cancer patients: A systematic literature review. [Review]. Patient Education and Counseling, 77, 8. doi: 10.1016/j.pec.2009.03.027

Basavanthappa. (2008). Community Health Nursing: Jaypee Brothers, Medical Publishers.

Catane, R., Cherny, N. I., Kloke, M., Tanneberger, S., \& Schrijvers, D. (2006). Handbook of Advanced Cancer Care. Oxon, United Kingdom: Taylor \& Francis.

Cunningham, G. (2005). Williams Obstetrics (22 ed.). New York: McGRAW-HILL.

Dinkes. (2012). Kegiatan Pengendalian Kanker di Jawa Timur (PPMK, Trans.) (pp. 5). Surabaya: Dinas Kesehatan Provinsi Jawa Timur.
Dunleavey, R. (2009). Cervical cancer : a guide for nurses. Chichester: John Wiley \& Sons Ltd.

Effendy, D. N. (1998). Dasar-Dasar Keperawatan Kesehatan Masyarakat: Egc.

Friedman, M. M., Bowden, V. R., \& Jones, E. (2003). Family nursing: research, theory \& practice: Prentice Hall.

Given, B. A., Given, C. W., \& Kozachik, S. (2001). Family Support in Advanced Cancer. CA A Cancer Journal for Clinicians, 51(4), 19.

Kerrigan, D., \& Kelly, J. (2010). Understanding Cancer and the Environment. Retrieved from

NCI. (2010). Cervical Cancer. Maryland, USA: National Cancer Institute.

Setyani, S. (2013). Terapkan 10 Indikator PHBS Dalam Lingkungan Keluarga. Retrieved from

http://www.promkes.depkes.go.id/inde x.php/topik-kesehatan/106-terapkan10-indikator-phbs-dalam-lingkungankeluarga

Setyowati, T., \& Lubis, A. (2003). Pemanfaatan pelayanan kesehatan dan jaminan pemeliharaan kesehatan (SUSENAS 2001). Buletin Penelitian Kesehatan, 31(4), 9.

WHO. (2010). Indonesia: Human Papiloma Virus and Related Cancers, Fact sheet 2010. Barcelona, Spanyol: WHO/ICO HPV Information Centre. 